\title{
Buchholzia Coriacea Exhibited Antinecrotic, Antioxidant and Anti-Inflammatory Potentials in the Sub-Acute Dose of Paracetamol Induced Toxicity
}

\author{
Fakoya A and Olusola $\mathrm{AO}^{*}$ \\ Department of Biochemistry, Faculty of Sciences, Adekunle Ajasin University, Akungba Akoko, Ondo State, Nigeria \\ *Corresponding author: Olusola AO, Department of Biochemistry, Faculty of Sciences, Adekunle Ajasin University, \\ Akungba Akoko, Ondo State, Nigeria
}

\section{ARTICLE INFO}

Received: 蔧 March 03, 2020

Published: 問 March 10, 2020

Citation: Fakoya A, Olusola AO. Buchholzia Coriacea Exhibited Antinecrotic, Antioxidant and Anti-Inflammatory Potentials in the SubAcute Dose of Paracetamol Induced Toxicity. Biomed J Sci \& Tech Res 26(3)-2020. BJSTR. MS.ID.004364.

Keywords: Inflammation, Upregulation, Repression; Apoptosis; Homogenized

Abbreviations: NAPQI: N -acetylp-Benzoquinone Imine; PCR: Polymerase Chain Reaction; APAP: N-Acetyl-PAminophenol; DISC: Death-Inducing Signaling Complex; TCR: T Cell Receptor; AICD: Activation-Induced Cell Death; CRP: C-Reactive Proteins; CBDD: BioComputing and Drug Development; PTGS: Prostaglandin Synthase Gene

\begin{abstract}
This study was designed to investigate the potential ameliorative effect of the ethanolic seed extract of Buchholzia coriacea in paracetamol-induced toxicities in male wistar rats using $\mathrm{N}$-acetyl cysteine as a standard drug. Thirty-two male wistar rats were used for the study. The animals were divided into eight groups according to their weights, with four rats in each group. Group 1 , which is the control, received only normal diet. Group 2 (negative control) received $14.28 \mathrm{mg} / \mathrm{kg}$ b.w of paracetamol daily. Groups 3 and 4 received $14.28 \mathrm{mg} / \mathrm{kg} \mathrm{b.w}$ of paracetamol each followed by 200 and $400 \mathrm{mg} / \mathrm{kg}$ b.w of extract after 6 hours of paracetamol administration respectively. Groups 5 and 6 each received $14.28 \mathrm{mg} / \mathrm{kg}$ b.w of paracetamol followed by 70 and $150 \mathrm{mg} / \mathrm{kg}$ b.w of $\mathrm{N}$-acetyl cysteine respectively after 6 hours of paracetamol administration. Groups 7 and 8 received 200 and $400 \mathrm{mg} / \mathrm{kg}$ b.w of extract respectively once daily. These treatments were given orally for 28 days. The animals were sacrificed and the organs (liver and kidney) were excised, homogenized and analyzed for gene expression using quantitative polymerase chain reaction and gel electrophoresis.
\end{abstract}

The results showed that the plant extract elicited upregulation of $\mathrm{GP}_{\mathrm{x}}-1$ and GST genes by replenishing glutathione store which is necessary for the detoxification of harmful substances and scavenging free radicals in the liver and kidney. There was repression of Fas Ligand by preventing cell damage that can lead to apoptosis. Also, the plant extract elicited down-regulation of COX-2 by acting as anti-inflammatory agents, repression of CYP1A2 by reducing nephrotoxicity, repression of IL- 6 by reducing inflammation and repression of KIM-1 by preventing kidney injury. Therefore, the results of this study showed that the extract of Buchholzia coriacea elicited anti-inflammatory, antinarcotic and antioxidant effect against liver and kidney damage induced by paracetamol.

\section{Introduction}

Liver is a very important organ of the body which is responsible for majority of metabolism needed by the body for good health. It makes many of the chemicals required by the body to function normally, it breaks down and detoxifies various metabolites, synthesizes proteins, and produces bio-chemicals necessary for digestion, and it also acts as a storage unit Kaplowitz [1]. The liver is highly specialized tissue consisting of mostly hepatocytes, regulates a wide variety of high-volume biochemical reactions Maton, et al. [2]. Furthermore, the kidney is another important organ of the body which is responsible for maintaining homeostasis in the body and is susceptible to certain drugs, environmental toxicants and protein overload Wasung, et al. [3]. The kidney also receives input from the parasympathetic nervous system, by way of the renal branches of the vagus nerve, although, the function of this is yet unclear Bard, et al. $[4,5]$. Nephrotoxicity is toxicity in the kidneys, it is a poisonous effect of some substances both toxic chemicals and medications on renal function. There are various forms that some drugs may affect renal function in more than one-way Galley [6]. 
Most cases of liver and kidney damage occur in people who have taken at least 10-15 grams more than twice the recommended dose of paracetamol (acetaminophen). But some people are more susceptible to acetaminophen toxicity and can experience liver and kidney damage even at the recommended dose. Buchholzia coriacea has been recorded to possess medicinal value and that is why in this study, it is tested experimentally by using the ethanolic extracts of Buchholzia coriacea to treat paracetamol toxicity and $\mathrm{N}$-acetyl cysteine used as the standard drug. It is believed that the evidence provided by this research would lead to the synthesis of a plant-based natural product in the treatment of paracetamol toxicity. When taken in normal therapeutic doses, paracetamol has been shown to be safe Heard [7]. Following a therapeutic dose, it is mostly converted to non-toxic metabolites via Phase II metabolism by conjugation with sulfate and glucoronide, with a small portion being oxidized via the cytochrome P450 enzyme system Dong, et al. [8]. Cytochromes P450 2E1 and 3A4 convert approximately 5\% of paracetamol to a highly reactive intermediary metabolite, $\mathrm{N}$-acetylp-benzoquinone imine (NAPQI) Heard [7,9].

Under normal conditions, NAPQI is detoxified by conjugation with glutathione to form cysteine and mercapturic acid conjugates Richardson [9]. In cases of paracetamol overdose, the sulfate and glucuronide pathways become saturated, and more paracetamol is shunted to the cytochrome P450 system to produce NAPQI. As a result, hepatocellular supplies of glutathione become depleted, as the demand for glutathione is higher than its regeneration Mitchell, et al. [10]. NAPQI therefore remains in its toxic form in the liver and reacts with cellular membrane molecules, resulting in widespread hepatocyte damage and death, leading to acute liver necrosis Dan and Cedarbaum [11]. In animal studies, the liver's stores of glutathione must be depleted to less than $70 \%$ of normal levels before liver toxicity occurs Richardson [9]. Recently, evident has shown that there is a gradual revival of interest in the use of medicinal plants, which has formerly been neglected in developing countries, because of its safety and less side effect especially when compared with synthetic drugs Bakebain, et al. [12]. Therefore, the present study aimed at evaluating the anti-inflammatory, antinecrotic and antioxidant properties of Buchholzia coriacea seeds, which would further enhance its utilization as food or medicine.

\section{Materials and Methods}

\section{Equipment and Laboratory Apparatus}

Polymerase Chain Reaction (PCR) machine (Multi-gene optimax), Thermocycler machine, (Multigene Optimax, USA), Refrigerator, Eppendorf tube, Desiccator, Table centrifuge (Biofuge, Germany), Spectrophotometer (JENWAY, UK), Gel electrophoresis machine (USA), Micropipette, Photophoresis (USA).

\section{Chemicals and Reagents}

N-acetyl cysteine, Ethidium bromide, Tracking dye, Iso-propyl ethanol, Acetaminophen (GSK paracetamol), Master mix (Biolabs,
New England), RNA snap kits (lysis solution), Tris-Borate EDTA (Biolabs New England), Agarose gel powder (Cleaver scientific LTD, England), Primers (Inqada Biotechnical Industries (Pty) LTD., South Africa), Nuclease-free water (Life Sciences advanced technologies, England), Reverse transcriptase (Biolabs New England), Random Primer (Biolabs New England), dNTPs (Biolabs New England). All chemicals and reagents used are of high analytical grade.

\section{Collection of Plant Materials}

The seeds of Buchholzia coriacea were gotten from Oja Oba Market at Ikare Akoko, Ondo State. Identification of the plant was done in the Department of Plant Science and Biotechnology, Adekunle Ajasin University, Akungba Akoko, Ondo State, Nigeria.

\section{Extraction Procedure}

Cold extraction method was employed. $500 \mathrm{~g}$ of the clean, air dried and pulverized plant sample was weighed into extraction jar and $1400 \mathrm{ml}$ of analytical grade ethanol was added to the jar containing Buchholzia coriacea. The extraction mixture was given periodic constant agitation and left for 72 hours. The supernatant was decanted and concentrated using rotary evaporator at $40^{\circ} \mathrm{C}$ and the extract was freeze-dried. The extract was packed inside an airtight sample bottle and kept at $4^{\circ} \mathrm{C}$ inside the refrigerator until when needed.

\section{Laboratory Animal}

Thirty-two (32) active male wistar rats were purchased from the University of Ibadan, Oyo State and they were acclimatized in favorable environment for four weeks. The animals were maintained and used in accordance with the guidelines of the Committee on Care and Use of Experimental Animal Resources, Faculty of Science, Adekunle Ajasin University, Akungba Akoko, Ondo State, Nigeria.

\section{Experimental Design}

Thirty-two male wistar rats were used for this study. The animals were divided into eight groups according to their weights, with four rats in each group. After acclimatization, group 1, which is the control, received only normal diet. Group 2 (negative control) received $14.28 \mathrm{mg} / \mathrm{kg}$ b.w of paracetamol daily. Group 3 received $14.28 \mathrm{mg} / \mathrm{kg}$ b.w of paracetamol and $200 \mathrm{mg} / \mathrm{kg}$ b.w of extract after 6 hours of paracetamol administration. Group 4 received $14.28 \mathrm{mg} /$ $\mathrm{kg}$ b.w of paracetamol and $400 \mathrm{mg} / \mathrm{kg}$ b.w of extract after 6 hours of paracetamol administration. Groups 5 and 6 received $14.28 \mathrm{mg} /$ $\mathrm{kg}$ b.w of paracetamol each followed by 70 and $150 \mathrm{mg} / \mathrm{kg}$ b.w of $\mathrm{N}$-acetyl cysteine respectively after 6 hours of paracetamol administration. Groups 7 and 8 received 200 and $400 \mathrm{mg} / \mathrm{kg}$ b.w of extract respectively once daily. These treatments were given orally for 28 days.

\section{Animal Sacrifice and Tissue Excision}

At the end of the 28 days period of stable administration, animals were fasted overnight and sacrificed the next morning. Tissues (kidney, liver) were excised into Eppendorf tubes containing 100ul 
RNA snap kit reagent across the groups. Tissues were homogenized and then stored in a refrigerator.

\section{Gene Expression Profiling}

Gene expression analysis: Total tissue RNA was extracted using TRIzol (Invitrogen) according to the manufacturer's protocol. RNA pellets were resuspended in diethyl/pyrocarbonate-treated deionized water. RNA samples were analyzed by agarose gel electrophoresis and integrity was confirmed by visualization of intact $18 \mathrm{~S}$ and 28S rRNA under UV light. Spectrophotometric study (NanoDrop, Thermo Scientific 2000c) was used to confirm the purity of total RNA and then its concentration was determined. The 1-2 $\mu \mathrm{g}$ RNA was reverse transcribed to $\mathrm{cDNA}$ at $42^{\circ} \mathrm{C}$ for 60 $\mathrm{min}$. After enzyme inactivation $\left(95^{\circ} \mathrm{C}, 10 \mathrm{~min}\right) \mathrm{cDNA}$ fragments were amplified for 35 cycles using gene-specific primers for the genes of interest. PCR products were resolved on $2 \%$ agarose gels and visualized using Uvitec gel documentation systems (Uvitec ArminTeb, Iran). Gene expression study was carried out by statistical analysis using Uvitec Fire Reader Software (Cambridge) to compare the groups.

\section{Results}

\section{Liver (Pre-Treatment with Paracetamol for Sub-Acute Study)}

Figures (1-6)

\section{Kidney (Pre-Treatment with Paracetamol for Sub-Acute Study)}

Figures (7-12)

\section{Discussion}

Liver and kidney damage induced by drugs are world wide's health problem. It is a major health issue that challenges not only health care professionals but also the pharmaceutical industry and drug regulatory agencies James, et al. [13]. Liver is one of the most important organs in the biotransformation of food, drugs, endogenous and exogenous substances. Profuse supply of blood and the presence of many redox systems (e.g., cytochromes and various enzymes) enable liver to convert these substances into different kinds of inactive, active or even toxic metabolites. The burden of metabolism and exposure to dangerous chemicals make liver vulnerable to a variety of disorders, such as acute or chronic inflammation, toxin or drug-induced hepatitis, cirrhosis and hepatitis after viral infection Sherlock and Dooley [14]. Kidney is another crucial organ. It functions in regulating blood and urine homeostasis in the body. It receives messages from the parasympathetic nervous system, meaning, it connects to the brain and the lower part of the spinal cord to affect its function Bard, et al. [4]. Kidney can also be exposed to poisonous substances that result in nephrotoxicity, such substances can either be chemicals or medications on renal function.

Acetaminophen (N-acetyl-p-aminophenol, APAP; paracetamol) is a commonly prescribed analgesic and antipyretic and its overdose can cause overproduction of ROS during formation of N-acetylp-benzoquinone imine (NAPQI) by cytochrome P450 leading to hepatic toxicity and nephrotoxicity Jaeschke, et al. [15]. As such, the United States Food and Drug Administration recommends $\mathrm{N}$-acetyl cysteine (NAC), a known antioxidant, as the only therapeutic option for APAP-overdosed patients Green, et al. [16]. However, this medication has its limitations including adverse effects and narrow therapeutic window Du, et al. [17]. Hence, the development of new drugs that are superior to NAC, in terms of effectiveness and therapeutic time frame, is clearly needed. In recent years, there have been intensive studies demonstrating the antioxidant and hepatoprotective effects of natural products against APAPinduced hepatotoxicity in experimental animals Ang-lee, et al. [18]. Therefore, we present this research work to demonstrate the significant effect of $\mathrm{B}$. coriacea extract as dose dependent protective measure against paracetamol induced hepatoxicity and nephrotoxicity.

\section{Glutathione Peroxidase-1 (GP -1$)$}

$\mathrm{GP}_{\mathrm{x}}-1$ is ubiquitously expressed in many tissues, where it protects cells from oxidative stress Brigelius-Flohé, et al. [19]. $\mathrm{GP}_{\mathrm{x}}-1$ gene produces a protein that protects us from the damaging effects of free radicals which can lead to tissue damage and speed up aging processes Higashi, et al. [20]. Within cells, it is concentrated on a particular spot of the cytoplasm and mitochondria Gouaze, et al. [21]. Glutathione peroxidase, $\mathrm{GP}_{\mathrm{x}}-1$, functions in the detoxification of hydrogen peroxide to water Straif, et al. [22]. The glutathione peroxidase also catalyzes the reduction of other organic hydroperoxides. $\mathrm{GP}_{\mathrm{x}}-1$ overexpression delays cell growth and protects them from $\mathrm{H}_{2} \mathrm{O}_{2}$ toxicity. It drains the cellular reduced GSH pool and therefore, has protective effect on endothelial cell lining Faucher, et al. [23]. From the result in (Figure 1), no significant difference was observed in the relative gene expression of $\mathrm{GP}_{\mathrm{x}}-1$ when all the groups were compared to one another. But figuratively, when paracetamol group (negative control) was compared to the basal control, there was a repression in the level of $\mathrm{GP}_{\mathrm{x}}-1$. 


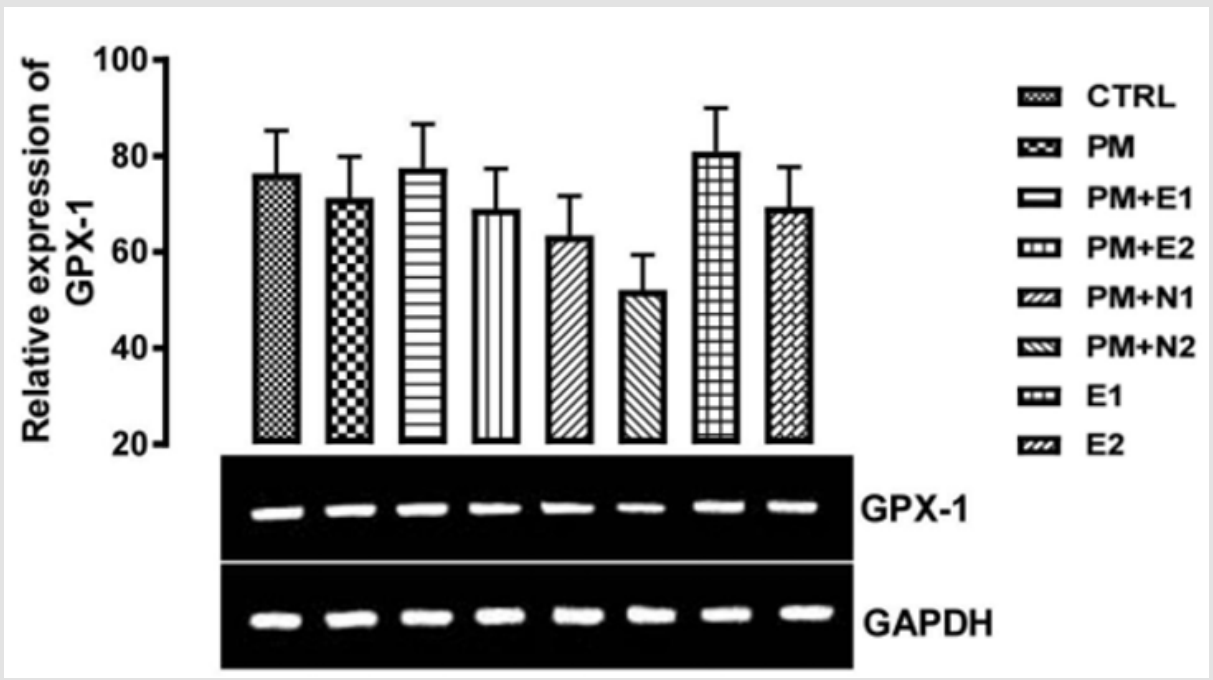

$\mathrm{P}<0.05$ (95\% confidence interval), Turkey post hoc test, 95.00\% CL ${ }^{*} \mathrm{p}<0.033,{ }^{* *} \mathrm{p}<0.002,{ }^{* * *} \mathrm{p}<0.001$.

Figure 1: The effects of Buccholzia coriacea extract and N-Acetyl cysteine on the expression of GPX-1 gene in the pre-treatment (Sub-acute) stage of paracetamol toxicity in kidney of wistar rats. PM=14.28mg/ kg body weight of paracetamol, E1=200mg/ $\mathrm{kg}$ body weight of B. coriacea, E2 $=400 \mathrm{mg} / \mathrm{kg}$ body weight of B. coriacea, $\mathrm{N} 1=70 \mathrm{mg} / \mathrm{kg}$ body weight of N-Acetyl cysteine, $\mathrm{N} 2=150 \mathrm{mg} / \mathrm{kg}$ body weight of N-Acetyl cysteine.

Paracetamol which was used to induce liver damage is an antipyretic drug at a normal dose, but at toxic dose, it causes the formation of free radicals and since $\mathrm{GP}_{\mathrm{x}}-1$ functions in protection against free radicals, it explains the reduction in the level of the gene in negative control group. When groups 3 to 8 were compared to the basal control and negative control, there was an upregulation in the level of $\mathrm{GP}_{\mathrm{x}}-1$ gene expressed with respect to both basal control and negative control groups. Although, in the group treated with $400 \mathrm{mg} / \mathrm{kg}$ extract alone, there was a high expression of the gene in comparison with other groups. According to Gupta and co-workers that worked on the hepatotoxic effect of Phytosome curcumin against paracetamol-induced liver toxicity, it was stated that Phytosome curcumin had a strong protective effect against paracetamol-induced acute hepatic damage in mice and the hepatoprotective effect of Phytosome curcumin may be explained by increasing levels of antioxidant enzymes and decreasing the lipid peroxidation and liver enzyme on paracetamol-induced damage in mice Gupta, et al. [24].

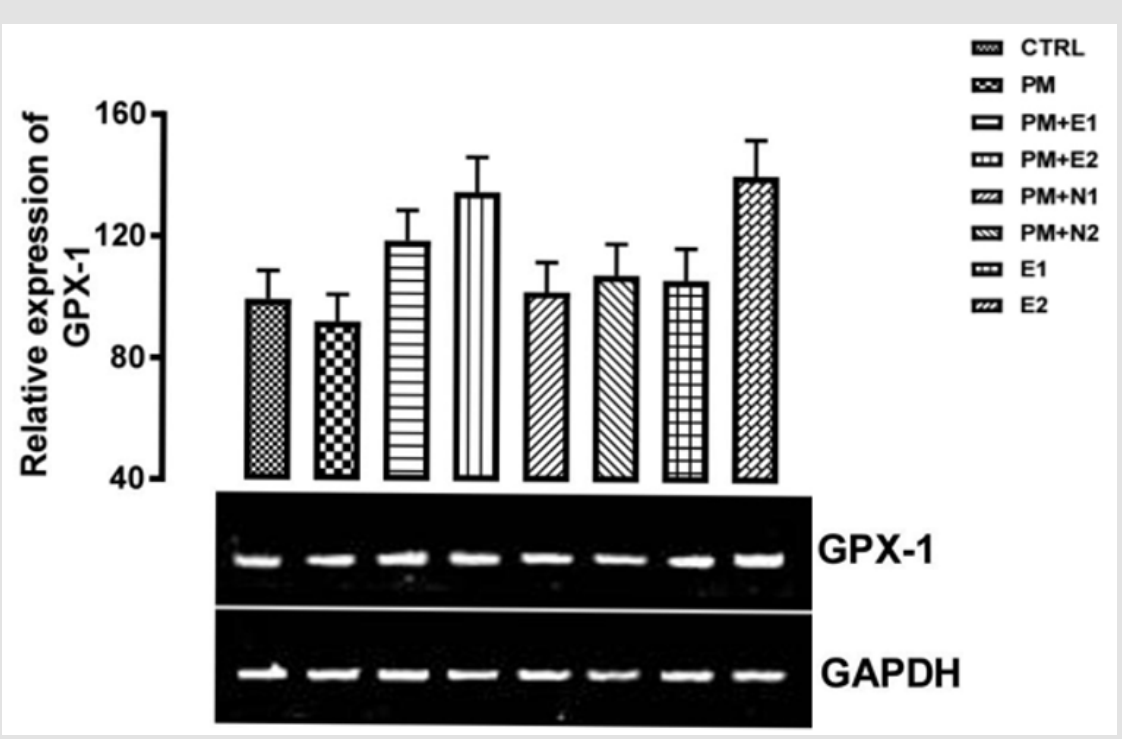

$\mathrm{P}<0.05$ (95\% confidence interval), Turkey post hoc test, $95.00 \% \mathrm{CL}{ }^{*} \mathrm{p}<0.033$, ${ }^{* *} \mathrm{p}<0.002,{ }^{* * *} \mathrm{p}<0.001$

Figure 2: The effects of Buccholzia coriacea extract and N-Acetyl cysteine on the expression of GP ${ }^{-1}$ gene in the pre-treatment (Sub-acute) stage of paracetamol toxicity in liver of wistar rats. PM=14.28mg $/ \mathrm{kg}$ body weight of paracetamol, E1=200mg/ $\mathrm{kg}$ body weight of $B$. coriacea, E2 $=400 \mathrm{mg} / \mathrm{kg}$ body weight of $B$. coriacea, $\mathrm{N} 1=70 \mathrm{mg} / \mathrm{kg}$ body weight of $\mathrm{N}$-Acetyl cysteine, $\mathrm{N} 2=$ $150 \mathrm{mg} / \mathrm{kg}$ body weight of N-Acetyl cysteine. 
Since phytochemicals (flavonoid) from plants have been described as free radicals' scavengers Murni, et al. [25], therefore, the consumption of Buchholzia coriacea extract at $400 \mathrm{mg} / \mathrm{kg}$ will be effective as an hepato-protective agent. In GPX-1 relative expression in the kidney as shown in (Figure 2), no significant difference was observed when the groups were all compared with each other. But figuratively, when paracetamol group was compared to the basal control, there was also a down-regulation in the level of GPX-1 gene expressed in the kidney. There was repression in the level of the gene expressed in the groups treated with $14.28 \mathrm{mg} /$ $\mathrm{kg}$ paracetamol and $400 \mathrm{mg} / \mathrm{kg}$ extract, $14.28 \mathrm{mg} / \mathrm{kg}$ paracetamol and $70 \mathrm{mg} / \mathrm{kg}$ NAC, $14.28 \mathrm{mg} / \mathrm{kg}$ paracetamol and $14.28 \mathrm{mg} / \mathrm{kg}$ paracetamol and $150 \mathrm{mg} / \mathrm{kg} \mathrm{NAC}$ and $400 \mathrm{mg} / \mathrm{kg}$ extract alone, when they were compared to the basal control and negative control. An upregulation was observed in the level of the gene in the groups treated with $14.28 \mathrm{mg} / \mathrm{kg}$ paracetamol and $200 \mathrm{mg} / \mathrm{kg}$ extract, and $200 \mathrm{mg} / \mathrm{kg}$ extract only when they were compared to both basal control and negative control, although there was more expression of the gene observed in the group treated with $200 \mathrm{mg} /$ $\mathrm{kg}$ extract alone. This explained that at $200 \mathrm{mg} / \mathrm{kg}$, the extract of B. coriacea, if taken as food/drug supplement, could be more effective for preventing nephrotoxicity that can result from paracetamol overdose.

\section{Cytochrome P450 1A2 (CYP1A2)}

Cytochrome P450 1A2 (abbreviated CYP1A2 ), a member of the cytochrome P450 mixed- function oxidase system, is involved in the metabolism of xenobiotics in the body. In humans, the
CYP1A2 enzyme is encoded by the CYP1A2 gene Nelson, et al. [26]. Of more than 300 identified P450 isozymes, CYP1A2 in chemical carcinogenesis play a critical role, and is classified as 'toxic' isoenzyme Borba, et al. [27]. The content of CYP1A2 in the liver is relatively high, carcinogens such as amino acids, aflatoxin, toxins and aromatic compounds are metabolized by CYP1A2 and eventually produce carcinogenic substances Chaudhry, et al. [28]. It has been observed that many drugs are metabolized by CYP1A2 Fleeman, et al. [29]. The main cytochrome P450 isoforms (CYP), which are thought to be responsible for APAP bioactivation, thus pomoting liver damage (hepatotoxicity), are, CYP1A2, CYP2E1, CYP2C9 and CYP3A4 Dong, et al. [8].

From the relative expression of CYP1A2 gene in the liver as shown in (Figure 3), statistically, no significant difference was observed in the level of the gene expressed when the groups were compared to each other. Figuratively, there was an upregulation in the expression of the gene level when the group treated with $14.28 \mathrm{mg} / \mathrm{kg}$ of paracetamol alone (negative control) was compared to the basal control. In case of sub-acute administration of paracetamol, there was an upregulation of CYP1A2 gene which induces the oxidation of the drug (paracetamol) to NAPQI (NAPQI at high concentration depletes GSH store and is therefore responsible for hepatotoxicity). In the group treated with $14.28 \mathrm{mg} /$ $\mathrm{kg}$ of paracetamol and $200 \mathrm{mg} / \mathrm{kg}$ of extract, and also the group treated with $14.28 \mathrm{mg} / \mathrm{kg}$ of paracetamol and $400 \mathrm{mg} / \mathrm{kg}$ of extract, a down-regulation was observed in the level of CYP1A2 gene when compared with the paracetamol group but an upregulation was observed when compared with the basal control.

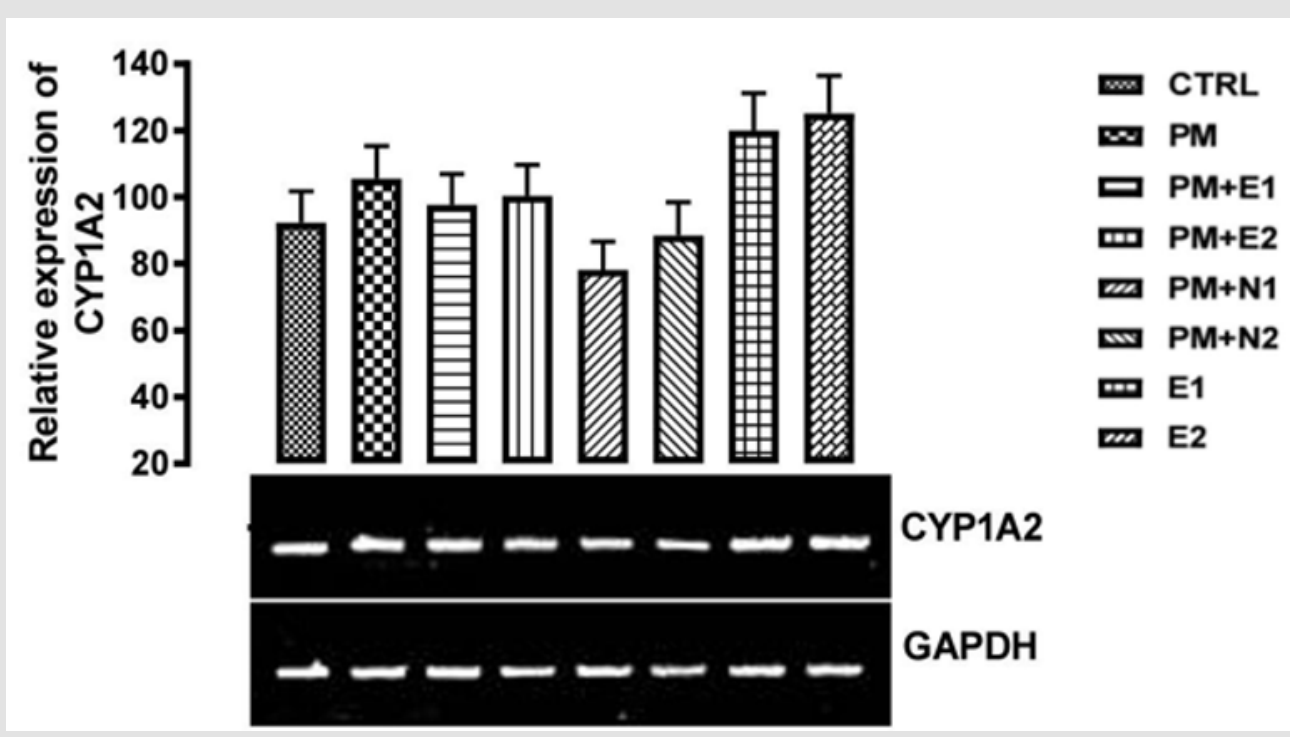

$\mathrm{P}<0.05$ (95\% confidence interval), Turkey post hoc test, $95.00 \% \mathrm{CL}{ }^{*} \mathrm{p}<0.033,{ }^{* *} \mathrm{p}<0.002,{ }^{* * *} \mathrm{p}<0.001$

Figure 3: The effects of Buccholzia coriacea extract and N-Acetyl cysteine on the expression of CYP1A2 gene in the pre-treatment (Sub-acute) stage of paracetamol toxicity in liver of wistar rats. $\mathrm{PM}=14.28 \mathrm{mg} / \mathrm{kg}$ body weight of paracetamol, E1 $=200 \mathrm{mg} /$ $\mathrm{kg}$ body weight of $B$. coriacea, E2= $400 \mathrm{mg} / \mathrm{kg}$ body weight of $B$. coriacea, N1=70mg $/ \mathrm{kg}$ body weight of $\mathrm{N}$-Acetyl cysteine, $\mathrm{N} 2=$ $150 \mathrm{mg} / \mathrm{kg}$ body weight of N-Acetyl cysteine. 
There was a down-regulation observed in the level of the gene in groups treated with $14.28 \mathrm{mg} / \mathrm{kg}$ of paracetamol and $70 \mathrm{mg} / \mathrm{kg}$ of NAC, $14.28 \mathrm{mg} / \mathrm{kg}$ of paracetamol and $150 \mathrm{mg} / \mathrm{kg}$ of NAC when compared to both basal control and negative control, although there was more decrease in the level of the gene observed in the group treated with $14.28 \mathrm{mg} / \mathrm{kg}$ of paracetamol and $70 \mathrm{mg} / \mathrm{kg}$ of NAC. In groups treated with only $200 \mathrm{mg} / \mathrm{kg}$ of extract and $400 \mathrm{mg} / \mathrm{kg}$ of extract respectively, an upregulation was observed in the gene level when compared to both basal control and negative control, this may imply that the treatments at the dosage of this extract is also able to increase the level of CYP1A2 in order to metabolise the chemical substance to useful therapeutic by-product. From the relative expression of CYP1A2 gene in the kidney as shown in (Figure 4), statistically, there was a significant difference at $\mathrm{p}<0.033$ when the group treated with $14.28 \mathrm{mg} / \mathrm{kg}$ of paracetamol and $150 \mathrm{mg} / \mathrm{kg}$ of NAC was compared with paracetamol treated group. Figuratively, there was an upregulation in the level of the gene expressed in the group treated with $14.28 \mathrm{mg} / \mathrm{kg}$ of paracetamol only (negative control) when compared with the basal control.

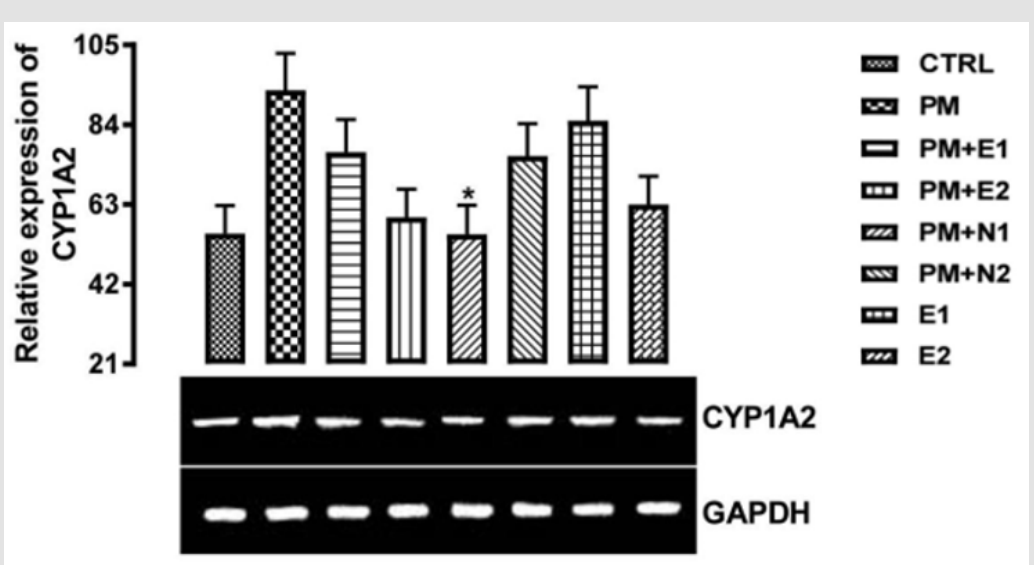

$\mathrm{P}<0.05$ (95\% confidence interval), Turkey post hoc test, $95.00 \% \mathrm{CL}{ }^{*} \mathrm{p}<0.033,{ }^{* *} \mathrm{p}<0.002,{ }^{* * *} \mathrm{p}<0.001$

Figure 4: The effects of Buccholzia coriacea extract and N-Acetyl cysteine on the expression of CYP1A2 gene in the pre-treatment (Sub-acute) stage of paracetamol toxicity in in kidney wistar rats. PM=14.28mg/ kg body weight of paracetamol, E1=200mg/ $\mathrm{kg}$ body weight of $B$. coriacea, E2 $=400 \mathrm{mg} / \mathrm{kg}$ body weight of $B$. coriacea, $\mathrm{N} 1=70 \mathrm{mg} / \mathrm{kg}$ body weight of $\mathrm{N}$-Acetyl cysteine, $\mathrm{N} 2=$ $150 \mathrm{mg} / \mathrm{kg}$ body weight of $\mathrm{N}$-Acetyl cysteine.

In the groups treated with $14.28 \mathrm{mg} / \mathrm{kg}$ of paracetamol and $200 \mathrm{mg} / \mathrm{kg}$ of extract, $14.28 \mathrm{mg} / \mathrm{kg}$ of paracetamol and $400 \mathrm{mg} / \mathrm{kg}$ of extract, $14.28 \mathrm{mg} / \mathrm{kg}$ of paracetamol and $70 \mathrm{mg} / \mathrm{kg}$ of NAC, $200 \mathrm{mg} /$ $\mathrm{kg}$ of extract only and $400 \mathrm{mg} / \mathrm{kg}$ of extract only, there was an upregulation in the level of CYP1A2 gene when compared with the basal control but a repression when compared with the negative control. Also, in the group treated with $14.28 \mathrm{mg} / \mathrm{kg}$ of paracetamol and $150 \mathrm{mg} / \mathrm{kg}$ of NAC, there was no difference in the level of the gene when compared with the basal control but a down-regulation was observed in the gene level when compared with negative control.

\section{Fas Ligand}

Fas (also called CD95 or APO-1 or TNFRSF6) is a type I transmembrane protein Ashkenazi, et al. [30], containing a death domain (DD) in its cytoplasmic region, which is essential for the induction of apoptosis Fesik [31]. The induction of apoptosis is triggered by the interaction of Fas with its ligand (FasL), a 40-kDa membrane protein Tanaka, et al. [32] allowing recruitment of the adaptor protein Fas-associated death domain (FADD) Peter, et al. [33] and binding of procaspase-8, resulting in the formation of the death-inducing signaling complex (DISC) Boatright, et al. [34], Apoptosis mediated by Fas-FasL is an important mechanism for the maintenance of immune homeostasis. During a physiological immunity response, programed cell death (apoptosis) has the important role to delete potentially pathogenic autoreactive lymphocytes from the circulation and tissues, limiting tissue damage inevitably caused by immune responses Chervonsky [35]. In fact, $\mathrm{T}$ cell receptor (TCR) restimulation of previously activated and expanded $\mathrm{T}$ cells in the absence of appropriate co-stimulation induces activation-induced cell death (AICD) Mercep, et al. [36], an important mechanism for removal of overly activated T cells, such as autoreactive $\mathrm{T}$ cells in autoimmune diseases.

From the relative expression of Fas ligand gene as shown in (Figure 5), statistically, there was no significant difference observed in the levels of the gene when all the groups were compared together. But figuratively, there was an upregulation in the level of Fas ligand gene expressed in group treated with paracetamol (negative control) in comparison with the basal control. This suggested that since the sub-acute dose of paracetamol may lead to liver injury and, studies have shown that the ligation of Fas with FasL results in the activation of a caspase cascade that initiates apoptosis (which occur from normal cell aging or as a result of cellular injury) Wolf, et al. [37]. In the groups treated with $14.28 \mathrm{mg} / \mathrm{kg}$ of paracetamol and $200 \mathrm{mg} / \mathrm{kg}$ of extract, $14.28 \mathrm{mg} / \mathrm{kg}$ of paracetamol and $70 \mathrm{mg} / \mathrm{kg}$ of NAC, $14.28 \mathrm{mg} / \mathrm{kg}$ of paracetamol and $150 \mathrm{mg} / \mathrm{kg}$ of NAC, $200 \mathrm{mg} /$ $\mathrm{kg}$ of extract and $400 \mathrm{mg} / \mathrm{kg}$ of extract, the expression of Fas $\mathrm{L}$ 
when compared to basal control was not as high as that of negative control. In the study carried out by Jin [38], it was discovered that the antioxidant effect of $\mathrm{N}$-acetylcysteine enables it to inhibit inflammation and apoptotic processes in human conjunctional epithelial cells in a high glucose environment. Based on our study, the extract was able to inhibit inflammation and apoptosis.

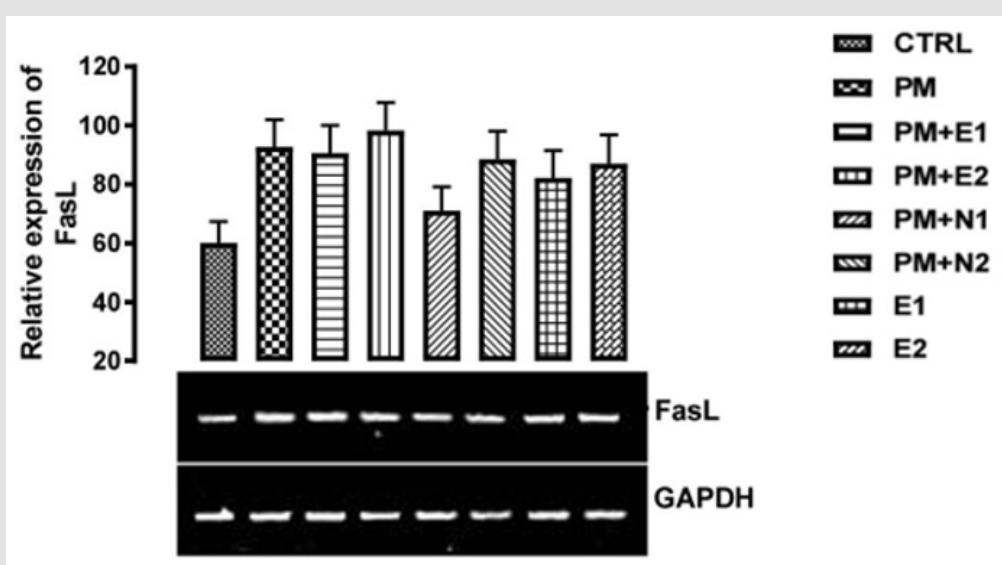

$\mathrm{P}<0.05$ (95\% confidence interval), Turkey post hoc test, $95.00 \% \mathrm{CL}{ }^{*} \mathrm{p}<0.033,{ }^{* *} \mathrm{p}<0.002,{ }^{* * *} \mathrm{p}<0.001$

Figure 5: The effects of Buccholzia coriacea extract and N-Acetyl cysteine on the expression of fasL gene in the pre-treatment (Sub-acute) stage of paracetamol toxicity in liver of wistar rats. PM=14.28mg $/ \mathrm{kg}$ body weight of paracetamol, E1=200mg/ $\mathrm{kg}$ body weight of $B$. coriacea, $\mathrm{E} 2=400 \mathrm{mg} / \mathrm{kg}$ body weight of $B$. coriacea, $\mathrm{N} 1=70 \mathrm{mg} / \mathrm{kg}$ body weight of $\mathrm{N}$-Acetyl cysteine, $\mathrm{N} 2=$ $150 \mathrm{mg} / \mathrm{kg}$ body weight of N-Acetyl cysteine.

From the relative expression of Fas ligand gene as shown in (Figure 6), statistically, there was no significant difference in the level of the gene expressed when all the groups were compared together. Figuratively, there was an upregulation in the level of the Fas ligand gene expressed when the group treated with $14.28 \mathrm{mg} /$ $\mathrm{kg}$ of paracetamol only, was compared to the basal control. In the groups treated with $14.28 \mathrm{mg} / \mathrm{kg}$ of paracetamol and $200 \mathrm{mg} / \mathrm{kg}$ of extract, $14.28 \mathrm{mg} / \mathrm{kg}$ of paracetamol and $400 \mathrm{mg} / \mathrm{kg}$ of extract, $14.28 \mathrm{mg} / \mathrm{kg}$ of paracetamol and $70 \mathrm{mg} / \mathrm{kg}$ of $\mathrm{NAC}, 14.28 \mathrm{mg} / \mathrm{kg}$ of paracetamol and $150 \mathrm{mg} / \mathrm{kg}$ of NAC and $400 \mathrm{mg} / \mathrm{kg}$ of extract, there was a downregulation in the expression of the gene when compared to negative control but an upregulation when compared to basal control. In the group treated with $200 \mathrm{mg} / \mathrm{kg}$ of extract, the level of the gene expressed was repressed in comparison with negative control but was the same with that of basal control. This result agrees with the study carried out by Wang and co-workers (2017) on the effect of Naringin on the expression level of apoptosis related gene, when treatment with Naringin markedly decreased the level of fas ligand gene in the kidney. Therefore, based on this experiment, it could be suggested that treatment with the extract $(200 \mathrm{mg} / \mathrm{kg})$ of B. coriaceacan offered a good measure to reduce kidney cell injury that can lead to apoptosis.

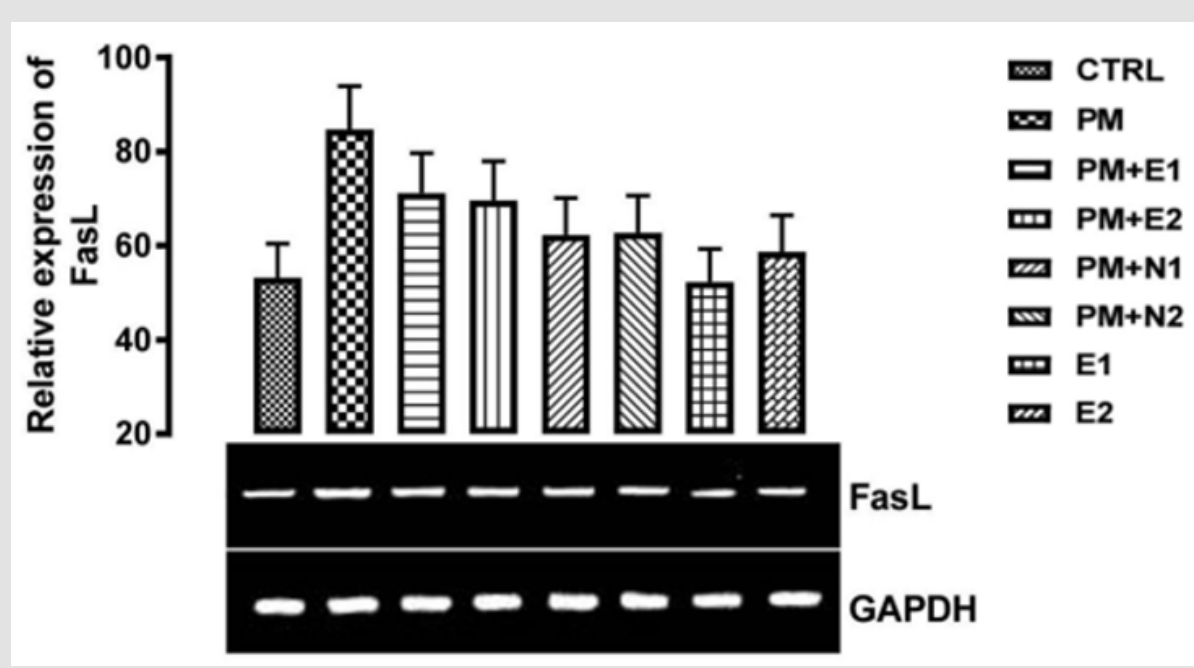

$\mathrm{P}<0.05$ (95\% confidence interval), Turkey post hoc test, $95.00 \% \mathrm{CL}{ }^{*} \mathrm{p}<0.033,{ }^{* *} \mathrm{p}<0.002,{ }^{* * *} \mathrm{p}<0.001$

Figure 6: The effects of Buccholzia coriacea extract and N-Acetyl cysteine on the expression of FasL gene in the pre-treatment (Sub-acute) stage of paracetamol toxicity in wistar rats. PM $=14.28 \mathrm{mg} / \mathrm{kg}$ body weight of paracetamol, E1=200mg/ $\mathrm{kg}$ body weight of $B$. coriacea, E2 $=400 \mathrm{mg} / \mathrm{kg}$ body weight of B. coriacea, $\mathrm{N} 1=70 \mathrm{mg} / \mathrm{kg}$ body weight of $\mathrm{N}$-Acetyl cysteine, $\mathrm{N} 2=150 \mathrm{mg} /$ $\mathrm{kg}$ body weight of $\mathrm{N}$-Acetyl cysteine. 


\section{Cyclooxygenase - $2(\mathrm{COX}-2)$}

COX-2 is an enzyme in humans that is encoded by the PTGS2 gene Hla, et al. [39]. In humans it is one of two cyclooxygenases. It is involved in the conversion of arachidonic acid to prostaglandin $\mathrm{H} 2$, an important precursor of prostacyclin, which is expressed in inflammation Rouzer, et al. [40]. COX-2 enzyme is also necessary for inflammation, a normal, healthy attempt by the body to heal itself. However, when inflammation gets out of control (such as in the case of arthritis, or other chronic inflammatory disorders) ongoing pain and discomfort is the result. That's where botanical COX-2 inhibitors can help. Botanical COX-2 inhibitors block the action of the COX2 enzyme, which helps reduce inflammation and pain. Rouzer, et al. [40]. From the relative expression of COX-2 gene as shown in (Figure 7), statistically, there was a significant difference at $\mathrm{p}<0.05$ in paracetamol group (negative control) when it was compared to the basal control. There was also a significant difference at $\mathrm{p}<0.033$ in the group treated with $14.28 \mathrm{mg} / \mathrm{kg}$ paracetamol and $70 \mathrm{mg} / \mathrm{kg}$ NAC when it was compared to the negative control group.

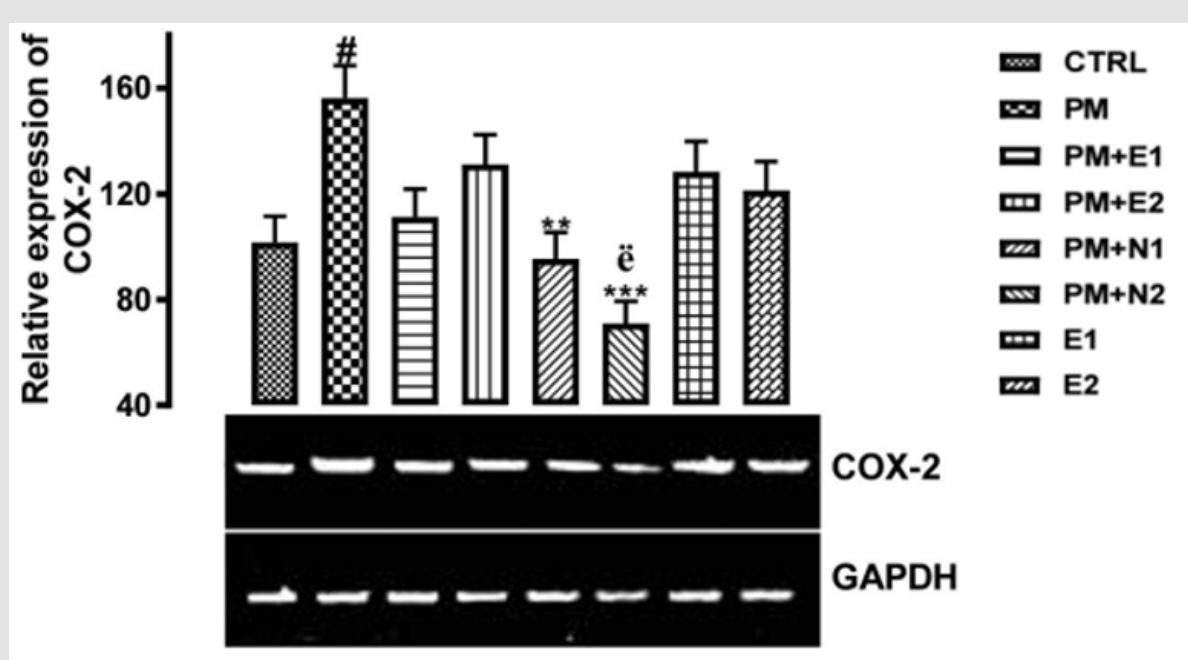

$\mathrm{P}<0.05$ (95\% confidence interval), Turkey post hoc test, $95.00 \% \mathrm{CL}{ }^{*} \mathrm{p}<0.033,{ }^{* *} \mathrm{p}<0.002,{ }^{* * *} \mathrm{p}<0.001$

Figure 7: The effects of Buccholzia coriacea extract and N-Acetyl cysteine on the expression of COX-2 gene in the pre-treatment (Sub-acute) stage of paracetamol toxicity in liver of wistar rats. $\mathrm{PM}=14.28 \mathrm{mg} / \mathrm{kg}$ body weight of paracetamol, E1= 200mg/ $\mathrm{kg}$ body weight of $B$. coriacea, E2 $=400 \mathrm{mg} / \mathrm{kg}$ body weight of $B$. coriacea, $\mathrm{N} 1=70 \mathrm{mg} / \mathrm{kg}$ body weight of $\mathrm{N}$-Acetyl cysteine, $\mathrm{N} 2=$ $150 \mathrm{mg} / \mathrm{kg}$ body weight of $\mathrm{N}$-Acetyl cysteine.

Likewise, a significant difference at $\mathrm{p}<0.001$ was observed when the group treated with $14.28 \mathrm{mg} / \mathrm{kg}$ paracetamol and $150 \mathrm{mg} /$ $\mathrm{kg}$ NAC when compared to the group treated with $14.28 \mathrm{mg} /$ $\mathrm{kg}$ paracetamol and $400 \mathrm{mg} / \mathrm{kg}$ extract. Figuratively, there was an upregulation in the expression of COX-2 when paracetamol group was compared to the basal control. Although, paracetamol is classified as a mild analgesic, Hochhauser [41], it does not have significant anti-inflammatory activity Mc Kay, et al. [42]. This explained why there was increase in the level of COX-2 gene in the group treated with paracetamol. There was an upregulation observed in the level of the COX-2 gene expressed in the groups treated with $14.28 \mathrm{mg} / \mathrm{kg}$ paracetamol and $200 \mathrm{mg} / \mathrm{kg}$ extract, $14.28 \mathrm{mg} / \mathrm{kg}$ paracetamol and $400 \mathrm{mg} / \mathrm{kg}$ extract, $200 \mathrm{mg} / \mathrm{kg}$ extract alone and $400 \mathrm{mg} / \mathrm{kg}$ extract alone when compared to basal control but a downregulation in the level of the gene was observed in the groups when compared to negative control. Studies have shown that the extract from B. coriacea has antimicrobial, antihelminticss and anti-inflammatory Ezekiel, et al. [43-45].

This explained that the extract at $200 \mathrm{mg} / \mathrm{kg}$ and $400 \mathrm{mg} / \mathrm{kg}$ respectively are able to downregulate the inflammatory property of paracetamol. There was a repression in the level of COX-2 gene when the groups treated with $14.28 \mathrm{mg} / \mathrm{kg}$ paracetamol and $70 \mathrm{mg} / \mathrm{kg}$ NAC, $14.28 \mathrm{mg} / \mathrm{kg}$ paracetamol and $150 \mathrm{mg} / \mathrm{kg}$ NAC were compared to both basal control and negative control, although the expression of the gene in the group treated with $14.28 \mathrm{mg} / \mathrm{kg}$ paracetamol and $150 \mathrm{mg} / \mathrm{kg}$ NAC was more repressed. Recent clinical trials suggest that $\mathrm{N}$-acetyl cysteine replenishes glutathione stores, scavenges hydroxyl free radicals and also has anti-inflammatory properties Dimari, et al. [46] and this confirms the study carried out by Erica, et al. [47] in which the anti-inflammatory property of NAC enables it to enhance the down-regulation of COX-2 gene induced by paracetamol toxicity. Likewise, in the treatment with $14.28 \mathrm{mg} /$ $\mathrm{kg}$ paracetamol and $150 \mathrm{mg} / \mathrm{kg}$ of NAC, NAC was able to repress the inflammatory property of paracetamol. Therefore, the result suggested that the extract was able to serve as an analgesic drug and also prevent inflammation caused by paracetamol toxicity.

\section{Glutathione S-Transferase (GST)}

The glutathione S-transferase (GST) gene family encodes genes that are critical for certain life processes, as well as for detoxication and toxification mechanisms, via conjugation of reduced glutathione (GSH) with numerous substrates such as pharmaceuticals and environmental pollutant Franco, et al. [48]. 
GSTs have multiple biological roles, including cell protection against oxidative stress and several toxic molecules, and are involved in the synthesis and modification of leukotrienes and prostaglandins Hayes, et al. [49]. As an example, GSTs protect cellular DNA against oxidative damage that can lead to an increase of DNA mutations or induce DNA damage promoting carcinogenesis Li, et al. [50]. GSTs are able to conjugate glutathione ( $\gamma$-l-glutamyl-l- cysteinyl-glycine, GSH) to a wide range of hydrophobic and electrophilic molecules including many carcinogens, therapeutic drugs, and many products of oxidative metabolism, making them less toxic and predisposed to further modification for discharge from the cell Hayes, et al. [49]. An analysis of the GST gene family in the human genome organizationsponsored human gene nomenclature committee database showed 21 putatively functional genes.

Its primary function is to detoxify xenobiotics by catalyzing the nucleophilic attack by GSH on electrophilic carbon, sulfur, or nitrogen atoms of specific nonpolar xenobiotic substrates, thereby preventing their interaction with crucial cellular proteins and nucleic acids Josephy $[51,49]$. The GST genes are upregulated in response to oxidative stress Bae [52]. From the relative expression of the GST gene in the liver as shown in (Figure 8), no significant difference was observed in the level of the gene expressed when all the groups were compared to one another. But figuratively, there was a little increase in the expression of the gene in the group treated with $14.28 \mathrm{mg} / \mathrm{kg}$ of paracetamol only when compared to the basal control. In the groups treated with $14.28 \mathrm{mg} / \mathrm{kg}$ of paracetamol and $70 \mathrm{mg} / \mathrm{kg}$ of $\mathrm{NAC}, 14.28 \mathrm{mg} / \mathrm{kg}$ of paracetamol and $150 \mathrm{mg} / \mathrm{kg}$ of NAC, there was a repression in the level of GST expressed in comparison with the basal control and the negative control. There was no observable difference in the level of GST gene that was expressed when compared to the basal control but there was a little repression when compared to negative control.

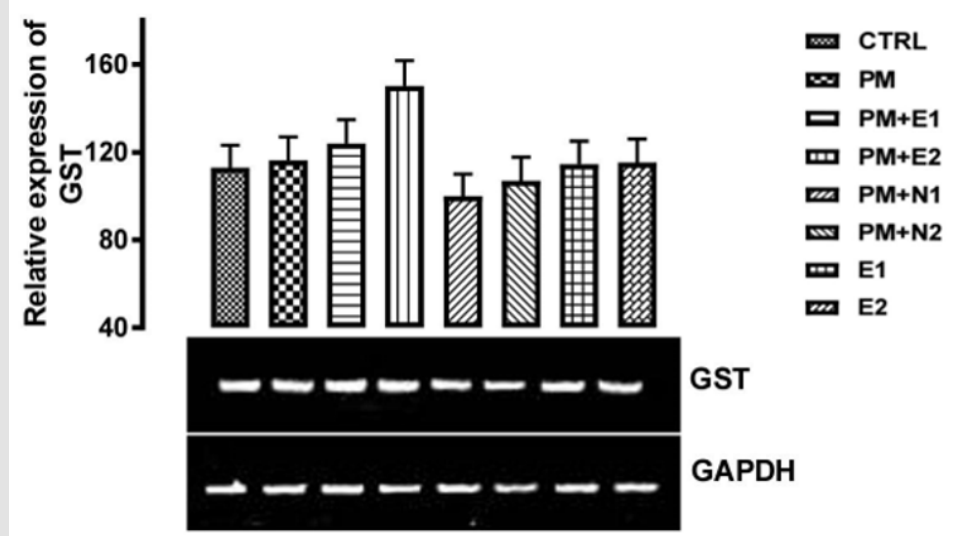

$\mathrm{P}<0.05$ (95\% confidence interval), Turkey post hoc test, 95.00\% CL * $\mathrm{p}<0.033$, ${ }^{* *} \mathrm{p}<0.002,{ }^{* * *} \mathrm{p}<0.001$

Figure 8: The effects of Buccholzia coriacea extract and N-Acetyl cysteine on the expression of GST gene in the pre-treatment (Sub-acute) stage of paracetamol toxicity in liver of wistar rats. PM= $14.28 \mathrm{mg} / \mathrm{kg}$ body weight of paracetamol, E1=200mg/ $\mathrm{kg}$ body weight of $B$. coriacea, E2 $=400 \mathrm{mg} / \mathrm{kg}$ body weight of $B$. coriacea, N1=70mg $/ \mathrm{kg}$ body weight of N-Acetyl cysteine, N2= $150 \mathrm{mg} / \mathrm{kg}$ body weight of N-Acetyl cysteine.

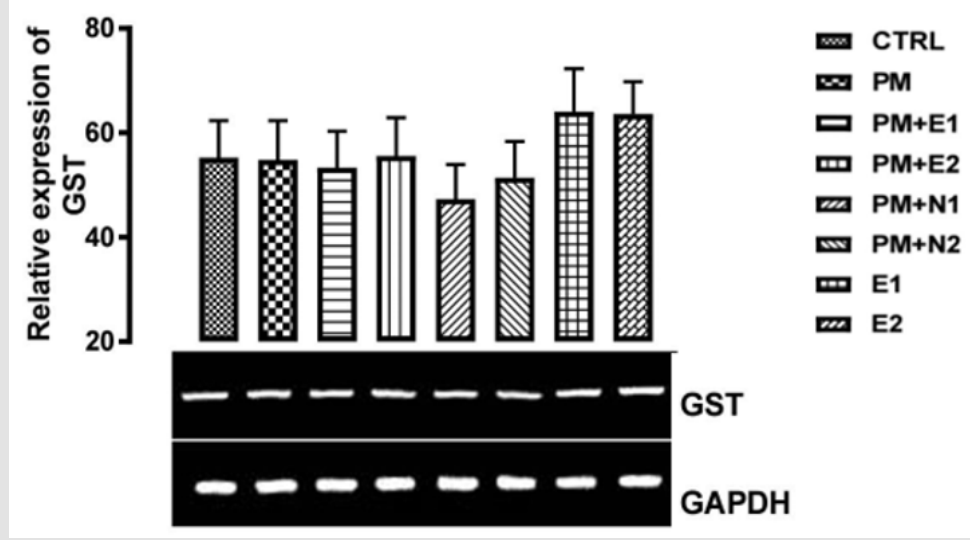

$\mathrm{P}<0.05$ (95\% confidence interval), Turkey post hoc test, $95.00 \% \mathrm{CL}{ }^{*} \mathrm{p}<0.033,{ }^{* *} \mathrm{p}<0.002,{ }^{* * *} \mathrm{p}<0.001$

Figure 9: The effects of Buccholzia coriacea extract and N-Acetyl cysteine on the expression of GST gene in the pre-treatment (Sub-acute) stage of paracetamol toxicity in kidney of wistar rats. $\mathrm{PM}=14.28 \mathrm{mg} / \mathrm{kg}$ body weight of paracetamol, E1=200mg/ $\mathrm{kg}$ body weight of $B$. coriacea, E2 $=400 \mathrm{mg} / \mathrm{kg}$ body weight of $B$. coriacea, $\mathrm{N} 1=70 \mathrm{mg} / \mathrm{kg}$ body weight of $\mathrm{N}-\mathrm{Ace}$ tyl cysteine, $\mathrm{N} 2=$ $150 \mathrm{mg} / \mathrm{kg}$ body weight of N-Acetyl cysteine. 
In the groups treated with $14.28 \mathrm{mg} / \mathrm{kg}$ of paracetamol and $200 \mathrm{mg} / \mathrm{kg}$ of extract, there was an upregulation in the level of the gene expressed when they were compared to both negative control and basal control, but the group treated with $14.28 \mathrm{mg} /$ $\mathrm{kg}$ of paracetamol and $400 \mathrm{mg} / \mathrm{kg}$ of extract upregulated the gene level more. Studies have shown that B. coriacea has wide range of medicinal effects. This explained why the group treated with paracetamol and the extract showed a high expression of the gene, and this is because the extract, when used with the paracetamol was able to mitigate the effect caused by paracetamol toxicity. Therefore, the extract could be a good hepatoprotective measure to reduce hepatotoxicity caused by paracetamol. From the relative expression of GST in the kidney as shown in (Figure 9), There was no statistical significant difference observed in the level of GST gene when the groups were compared with one another but figuratively, In the group treated with paracetamol only (negative control), there was a little repression in the level of the gene when compared with the basal control.

There was a down - regulation observed in the level of GST in the groups treated with $14.28 \mathrm{mg} / \mathrm{kg}$ of paracetamol and $70 \mathrm{mg} /$ $\mathrm{kg}$ of NAC, $14.28 \mathrm{mg} / \mathrm{kg}$ of paracetamol and $150 \mathrm{mg} / \mathrm{kg}$ of NAC and $14.28 \mathrm{mg} / \mathrm{kg}$ of paracetamol and $200 \mathrm{mg} / \mathrm{kg}$ of extract when compared with the negative control and basal control. Also, in the groups treated with $14.28 \mathrm{mg} / \mathrm{kg}$ of paracetamol and $400 \mathrm{mg} /$ $\mathrm{kg}$ of extract, $200 \mathrm{mg} / \mathrm{kg}$ of extract only and $400 \mathrm{mg} / \mathrm{kg}$ of extract only, there was an upregulation observed in the level of the gene when compared to the basal control and negative control, although there was more increase in the level of the gene in the group treated with $200 \mathrm{mg} / \mathrm{kg}$ of extract.. This extract from B. coriacea (if taken as food/drug supplement) can be effective to induce increase in expression of GST for detoxification of harmful chemicals in the kidney and liver.

\section{Interleukin-6 (IL-6)}

Interleukin-6 is an interleukin that act as a pro-inflammatory cytokine and in human; it is encoded by the interleukin- 6 gene Ferguson-smith, et al. [53]. After IL-6 is synthesized in a local lesion in the initial stage of inflammation, it moves to the liver through the blood stream, followed by the rapid induction of an extensive range of acute phase proteins such as C-reactive proteins (CRP), serum ameloid A (SAA), fibronogen, haptoglobin and $\alpha 1$-antichymotrypsin (Heinrich, et al. [54]. When high concentration of SAA persists for a long time, it leads to a serious complication of several chronic inflammatory diseases through the generation of amyloid A amyloidosis and this results in amyloid fibril deposition which causes progressive deterioration in various organs Gillmore, et al. [55]. IL-6 is involved in the regulation of serum iron and zinc levels via control of their transporters. As for serum iron, IL-6 induces hepcidin production which blocks the action of iron transporter ferroportin 1 on gut and thus reduces serum iron level Nemeth, et al. [56]. This means that, the IL-6 hepcidin access is responsible for hypoferrinia and anaemia associated with chronic inflammation.

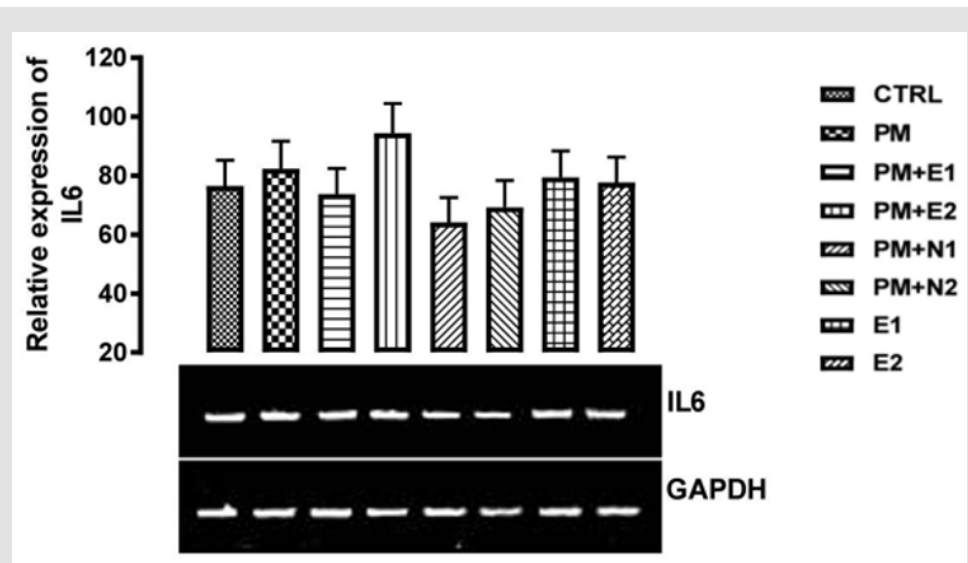

$\mathrm{P}<0.05$ (95\% confidence interval), Turkey post hoc test, $95.00 \% \mathrm{CL}{ }^{*} \mathrm{p}<0.033,{ }^{* *} \mathrm{p}<0.002,{ }^{* * *} \mathrm{p}<0.001$

Figure 10: The effects of Buccholzia coriacea extract and N-Acetyl cysteine on the expression of IL6 gene in the pre-treatment (Sub-acute) stage of paracetamol toxicity in liver of wistar rats. PM=14.28mg $/ \mathrm{kg}$ body weight of paracetamol, E1=200mg/ $\mathrm{kg}$ body weight of $B$. coriacea, E2 $=400 \mathrm{mg} / \mathrm{kg}$ body weight of $B$. coriacea, $\mathrm{N} 1=70 \mathrm{mg} / \mathrm{kg}$ body weight of $\mathrm{N}$-Acetyl cysteine, $\mathrm{N} 2=$ $150 \mathrm{mg} / \mathrm{kg}$ body weight of N-Acetyl cysteine.

IL-6 also enhances zinc importer (ZIP14) expression on hepatocytes and so induces hypozincemia seen in inflammation Luizzi, et al. [57]. From the relative expression of IL-6 gene as shown in (Figure 10), there was no statistical difference when all the groups were compared to each other. But figuratively, there was an upregulation in the expression of IL-6 in the group treated with paracetamol (negative control) when compared to basal control.
While paracetamol is classified as an antipyretic drug, it does not have any significant anti-inflammatory activity McKay, et al. [42] which explains the upregulation in the level of gene in group treated with paracetamol Hochhauser [41]. A down-regulation in the level of the gene was also observed in the groups treated with $14.28 \mathrm{mg} /$ $\mathrm{kg}$ paracetamol and $200 \mathrm{mg} / \mathrm{kg}$ extract, $14.28 \mathrm{mg} / \mathrm{kg}$ paracetamol and $70 \mathrm{mg} / \mathrm{kg} \mathrm{NAC}, 14.28 \mathrm{mg} / \mathrm{kg}$ paracetamol and $150 \mathrm{mg} / \mathrm{kg}$ NAC 
when compared to basal control and negative control respectively. Nevertheless, the group treated with $14.28 \mathrm{mg} / \mathrm{kg}$ paracetamol and $70 \mathrm{mg} / \mathrm{kg}$ NAC showed more repression of the gene.

There was an up-regulation in the level of the gene in the gene treated with $14.28 \mathrm{mg} / \mathrm{kg}$ paracetamol and $400 \mathrm{mg} / \mathrm{kg}$ when compared to basal and negative control. In the group treated with $400 \mathrm{mg} / \mathrm{kg}$ extract alone, a down-regulation was observed in the level of the gene when compared with negative control but there was no difference when compared with basal control. In the group treated with $200 \mathrm{mg} / \mathrm{kg}$ extracted, a little upregulation was observed in the level of the gene when compared to basal control, but a down-regulation was observed for negative control. Based on the result from the experiment carried out by Ibiam [58], ethanolic extract of B. coriacea was proven to have anti-inflammatory potential which could be attributed to phytochemical components acting individually or collectively as seen in some of the groups treated with extract. But NAC has been scientifically proven to have a higher rate of antioxidant and anti-inflammatory properties Mata, et al. [59], which is in accordance with the previous report on the study carried out by Laura [60]. where pre-treatment and posttreatment with NAC in paracetamol administration diminished the elevation of interleukin 6 gene. This explains the downregulation in the group treated with paracetamol and $70 \mathrm{mg} / \mathrm{kg}$ NAC. Though NAC is good as an anti-inflammatory drug, it can be suggested that treatment with extracts of B. coriacea would also serve as a potent anti-inflammatory agent and could be a good reparative drug in treating kidney injury.

\section{Prostaglandin Synthase}

Prostaglandin synthase, also known as cyclooxygenases (COX-1 and COX-2) is an enzyme in humans that is encoded by prostaglandin synthase gene (PTGS gene) Funk, et al. [61]. Prostaglandins
(PGs) are bioactive lipids formed by the sequential actions of PG synthases Smith, et al. [62]. Prostaglandins play a key role in the generation of the inflammatory response. Their biosynthesis is significantly increased in inflamed tissue and they contribute to the development of the cardinal signs of acute inflammation. While the pro-inflammatory properties of individual prostaglandins during the acute inflammatory response are well established Tilley, et al. [63]. COX-1 is normally present in a variety of areas of the body, including not only the stomach but any site of inflammation Laine, et al. [64]. COX-2 expression is induced in macrophages, fibroblasts, vascular endothelial cells and smooth muscle cells by shear stress, cytokines, and growth factors and accounts for PG formation during inflammatory responses, reproduction, and renal adaptation to systemic stress Herschman, et al. [65].

From the relative expression of prostaglandin synthase gene as shown in (Figure 11), there was no statistically significant difference observed in the level of the gene expressed when all the groups were compared together. But figuratively, there was an upregulation in the level of the gene expressed in the group treated with $14.28 \mathrm{mg} / \mathrm{kg}$ of paracetamol (negative control) when it was compared to basal control. Although, paracetamol is classified as a mild analgesic, Hochhauser [41], it does not have significant antiinflammatory activity Mc Kay, et al. [42]. This explains why there was increase in the level of prostaglandin synthase gene in the group treated with paracetamol. In the groups treated with $14.28 \mathrm{mg} / \mathrm{kg}$ of paracetamol and $200 \mathrm{mg} / \mathrm{kg}$ of extract, $14.28 \mathrm{mg} / \mathrm{kg}$ of paracetamol and $400 \mathrm{mg} / \mathrm{kg}$ of extract, $14.28 \mathrm{mg} / \mathrm{kg}$ of paracetamol and $70 \mathrm{mg} /$ $\mathrm{kg}$ of NAC, $14.28 \mathrm{mg} / \mathrm{kg}$ of paracetamol and $150 \mathrm{mg} / \mathrm{kg}$ of NAC, $200 \mathrm{mg} / \mathrm{kg}$ of extract only and $400 \mathrm{mg} / \mathrm{kg}$ of extract only, there was an upregulation in the level of the gene when compared to basal control but a down-regulation when compared to negative control.

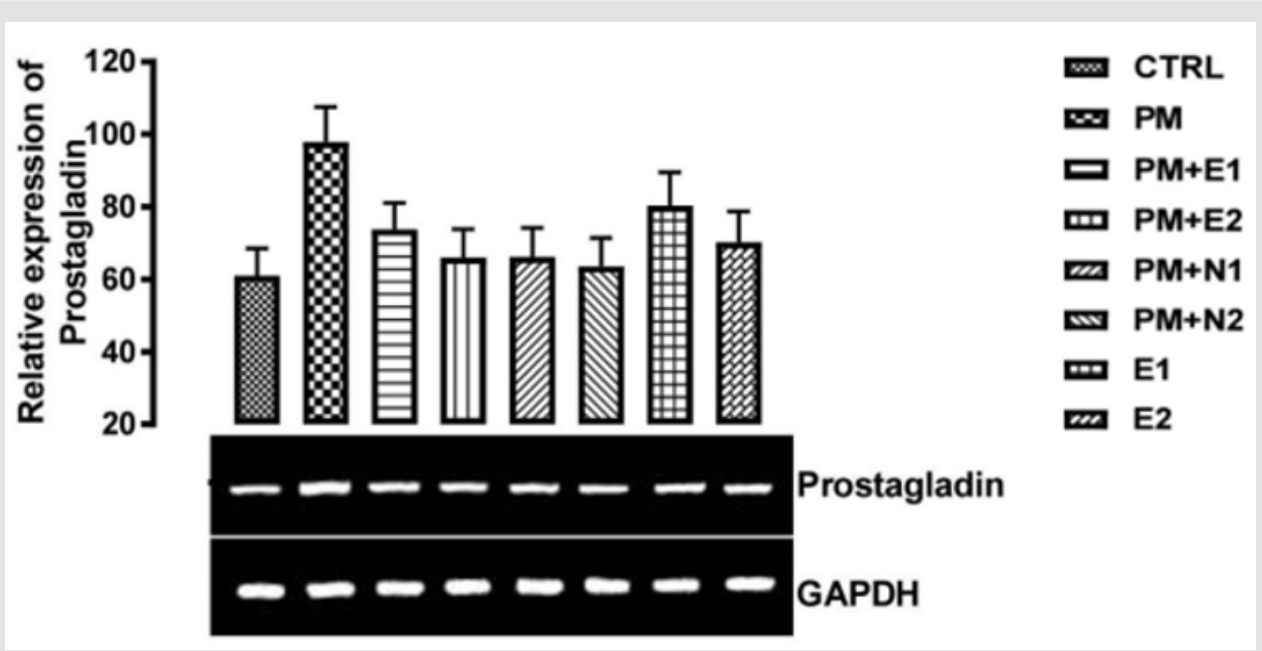

$\mathrm{P}<0.05$ (95\% confidence interval), Turkey post hoc test, $95.00 \% \mathrm{CL}{ }^{*} \mathrm{p}<0.033,{ }^{* *} \mathrm{p}<0.002,{ }^{* * *} \mathrm{p}<0.001$

Figure 11: The effects of Buccholzia coriacea extract and N-Acetyl cysteine on the expression of Prostaglandin synthase gene in the pre-treatment (Sub-acute) stage of paracetamol toxicity in kidney of wistar rats. PM= $14.28 \mathrm{mg} / \mathrm{kg}$ body weight of paracetamol, E1 $=200 \mathrm{mg} / \mathrm{kg}$ body weight of $B$. coriacea, E2 $=400 \mathrm{mg} / \mathrm{kg}$ body weight of B. coriacea, N1=70mg $/ \mathrm{kg}$ body weight of $\mathrm{N}$-Acetyl cysteine, $\mathrm{N} 2=150 \mathrm{mg} / \mathrm{kg}$ body weight of N-Acetyl cysteine. 
Although, the group treated with $14.28 \mathrm{mg} / \mathrm{kg}$ of paracetamol and $150 \mathrm{mg} / \mathrm{kg}$ of NAC showed more repression of the gene in comparison with negative control. Based on recent clinical trials that suggest that $\mathrm{N}$-acetyl cysteine replenishes glutathione stores, scavenges hydroxyl free radicals and also has anti-inflammatory properties Dimari, et al. [46], which is confirmed in the study carried out by Ancha $[66,67]$ where treatment with NAC suppressed prostaglandin synthase expression to control values in TNBSinduced colitis in rats. Also, the expression pattern of prostaglandin synthetase on the graph has shown that the B. coriacea extract was able to elicit physiological effect on diseased kidney. The expression of prostaglandin that was repressed confirmed the report by Mosly, et al. [68] on the use of pharmacological agents to ameliorate the symptoms of kidney inflammation. Therefore, I suggest that though NAC is good as an anti-inflammatory drug, treatment with extracts of B. coriacea can also serve as an alternate natural potent antiinflammatory agent and in combination as an adjuvant, could be a good reparative drug in treating kidney injury.

\section{Kidney Injury Molecule-1 (KIM-1)}

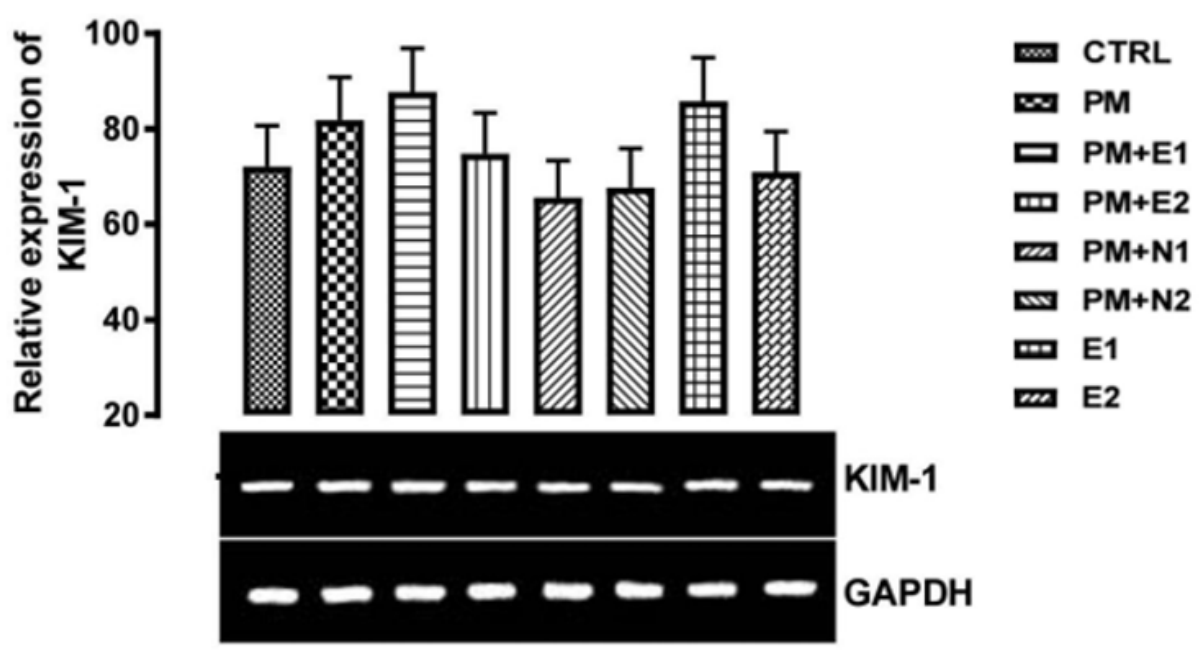

$\mathrm{P}<0.05$ (95\% confidence interval), Turkey post hoc test, $95.00 \% \mathrm{CL}{ }^{*} \mathrm{p}<0.033$, ${ }^{* *} \mathrm{p}<0.002,{ }^{* * *} \mathrm{p}<0.001$

Figure 12: The effects of Buccholzia coriacea extract and N-Acetyl cysteine on the expression of KIM-1 gene in the pre-treatment (Sub-acute) stage of paracetamol toxicity in kidney of wistar rats. PM=14.28mg $/ \mathrm{kg}$ body weight of paracetamol, E1=200mg/ $\mathrm{kg}$ body weight of $B$. coriacea, E2 $=400 \mathrm{mg} / \mathrm{kg}$ body weight of $B$. coriacea, N1=70mg $/ \mathrm{kg}$ body weight of $\mathrm{N}$-Acetyl cysteine, $\mathrm{N} 2=$ $150 \mathrm{mg} / \mathrm{kg}$ body weight of N-Acetyl cysteine.

Kidney injury molecule -1, also known as T cell immunoglobulin and mucin-1 (TIM-1) and hepatitis A virus cellular receptor 1(Havcr1) is a type 1 cell membrane glycoprotein Yang, et al. [69]. KIM-1 plays critical roles in regulating immune cell activity especially regarding the host response to viral infection. KIM-1 is also involved in allergic response, asthma, and transplant tolerance Meyers, et al. [70]. Kim-1 mRNA levels are elevated more than any known gene in rodents and humans after the initiation of kidney injury Lim, et al. [71,72]. Urinary Kim-1 has been shown to be a sensitive and early diagnostic indicator of renal injury in a variety of acute and chronic rodent kidney injury models Vaidya, et al. [72] and it was subsequently shown that KIM-1 is also a sensitive marker for kidney injury in children undergoing cardiac surgery Han, et al. [73]. Sancho-Martnez, et al. [74] investigated the use of measuring the mRNA expression or protein levels of KIM-1 and other biomarkers to detect nephrotoxicity in vitro. The expression of KIM-1 mRNA was previously reported to be markedly induced in rats in response to renal injury caused by cisplatin Ichimura, et al. [75]. From the relative expression of KIM-1 gene as shown in (Figure 12), no statistically significant difference was observed in the expression of the gene when all the groups were compared to one another.

Figuratively, when the group treated with just paracetamol alone (negative control) was compared to the basal control, there was an upregulation in the level of expression of KIM-1 gene in paracetamol group. The basic explanation to this is shown in an in-vitro data where paracetamol in therapeutic and toxic dose induced fibroblast proliferation, thereby resulting in kidney injury Yu, et al. [76]. There was an upregulation in the level of KIM-1 gene expressed in the groups treated with $14.28 \mathrm{mg} / \mathrm{kg}$ paracetamol and $200 \mathrm{mg} / \mathrm{kg}$ extract and $200 \mathrm{mg} / \mathrm{kg}$ extract alone when they were compared to the basal control and negative control. There was neither upregulation nor downregulation in the level of KIM-1 gene expressed when the group treated with $400 \mathrm{mg} / \mathrm{kg}$ extract was compared to the basal control group but there was a repression when compared to the paracetamol group, which implies that if $400 \mathrm{mg} / \mathrm{kg}$ of extract is taken as food supplement or as drug, it can useful as a measure to reduce nephrotoxicity. In the

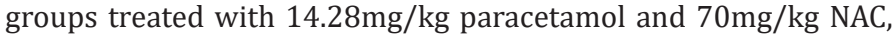
$14.28 \mathrm{mg} / \mathrm{kg}$ paracetamol and $150 \mathrm{mg} / \mathrm{kg}$, a downregulation was 
observed in the level of KIM-1 gene expressed. When the group treated with $14.28 \mathrm{mg} / \mathrm{kg}$ paracetamol and $400 \mathrm{mg} / \mathrm{kg}$ extract was compared to the control group, there was an upregulation observed in the level of the gene but a repression in the gene level when compared to paracetamol (negative control). According to the experiment carried out by Sao $[77,78]$ on the protective effect of $\mathrm{N}$-acetylcysteine on kidney as a remote organ after skeletal muscle ischemia-reperfusion, it was concluded that administration of $\mathrm{N}$-acetylcysteine treatment significantly decreased renal injury by skeletal muscles ischemia-reperfusion. Likewise, in this study, NAC was able to lessen the effect of paracetamol and therefore, I suggest that intake of $70 \mathrm{mg} / \mathrm{kg}$ NAC may be effective in preventing nephropathy induced by paracetamol toxicity.

\section{Conclusion}

Based on the present studies, Buchholzia coriacea could be studied for its possible antigenotoxic and biosafety before being considered for clinical trials as potent cytoprotective agent in the treatment of paracetamol induced nephro- and hepatotoxicities.

\section{Acknowledgements}

We are grateful to all the researchers at the Centre for Biocomputing and Drug Development Unit (CBDD), Department of Biochemistry, Faculty of Science, Adekunle Ajasin University, Akungba Akoko, Ondo State for their support during this research work.

\section{References}

1. Kaplowitz N (2000) Mechanism of liver cell injury. J Hepatol 32: 39-47.

2. Maton A, Jean H, Charles WM, Susan J, Maryanna QW, et al. (2004) Human Biology and Health. Englewood Cliffs, Prentice Hall, New Jersey, USA.

3. Wasung ME, Chawla LS, Madero M (2015) Biomarkers of renal function, which and when? Clin Chim Acta 438: 350-357.

4. Bard J, Vize PD, Woolf AS (2013) The kidney from normal development to congenital disease. Boston Academic Press. pp. 154.

5. Schrier B, Robert W, Berl Tomas, Harbottle T, Judith A, et al. (1972) Mechanism of the Antidiuretic Effect Associated with Interruption of Parasympathetic Pathway. Journal of Clinical Investigation 51(10): 2613-2620.

6. Galley HF (2007) Can acute renal failure be prevented? J R Coll Surg Edinb 45(1): 44-50.

7. Heard K J (2008) Acetylcysteine for Acetaminophen Poisoning. The New England Journal of Medicine 359(3): 285-292.

8. Dong H, Haining RL, Thummel KE (2000) Involvement of human cytochrome P450 2D6 in the bioactivation of acetaminophen. Drug Metab Dispos 28(12): 1397-1400.

9. Richardson JA (2007) Management of acetaminophen and ibuprofen toxicoses in dogs and cats. Journal of Veterinary Emergency and Critical Care 10(4): 285-291.

10. Mitchell JR, Jollow DJ, Potter WZ, Gillette JR, Brodie BB, et al (1973) Acetaminophen-induced hepatic necrosis IV Protective role of glutathione. The Journal of Pharmacology and Experimental Therapeutics 187(1): 211-217.

11. Dan Y, Cedarbaum AI (1995) Cytotoxicity of acetaminophen in human cytochrome P4502E1-transfected HepG2 cells. The Journal of Pharmacology and Experimental Therapeutics 273(3): 1497-1505.
12. Bakebain DA, Giami SY (1992) Proximate composition of full fat fluted pumpkin (Telfairia occidentalis) seed flour. J Sci food Agric 59: 321-325.

13. James LP, Mayeux PR, Hinson JA (2010) Acetaminophen-induced hepatotoxicity. Drug Metab Dispos 31: 1499-1506.

14. Sherlock S, Dooley J (2002) Drugs and the Liver in Diseases of Live and Biliary System. (11 ${ }^{\text {th }}$ Edn.). Blackwell Scientific Publications London pp. 335-365.

15. Jaeschke H, McGill MR, Williams CD, Ramachandran A (2011) Current issues with acetaminophen hepatotoxicity a clinically relevant model to test the efficacy of natural products. Life Sci 88: 737-745.

16. Green JL, Heard KJ, Reynolds KM, Albert D (2013) Oral and Intravenous Acetylcysteine for Treatment of Acetaminophen Toxicity, A Systematic Review and Meta-analysis. The Western Journal of Emergency Medicine 14(3): 218-226.

17. Du K, Ramachandran A, Jaeschke H (2016) Oxidative stress during acetaminophen hepatotoxicity. pathophysiological role and therapeutic potential. Redox Biol 10: 148-156.

18. Ang Lee MK, Moss J, Yuan CS (2001) Herbal medicines and perioperative care. JAMA 286(2): 208-216.

19. Brigelius Flohé R, Majorino M (2013) Glutathione peroxidases. Biochimica et Biophysica Acta 1830(5): 3289-3303.

20. Higashi Y, Pandey A, Goodwin B, Delafontaine P (2013) Insulin-like growth factor-1 regulates glutathione peroxidase expression and activity on vascular endothelial cells Implications for atheroprotective actions of insulin-like growth factor-1. Biochimica et Biophysica Acta 1832(3): 391-399.

21. Gouaze V, Andrieu Abadie N, Cuvillier O, Malagarie Cazenave S, Frisach MJ, et al. (2002) Glutathione peroxidase-1 protects from CD95-induced apoptosis. The Journal of Biological Chemistry 277(45): 42867-42874.

22. Straif D, Werz O, Kellner R, Bahr U, Steinhilber D, et al. (2000) Glutathione peroxidase-1 but not -4 is involved in the regulation of cellular 5-lipoxygenase activity in monocytic cells. The Biochemical Journal 349(Pt 2): 455-461.

23. Faucher K, Rabinovitch Chable H, Barrière G, Cook Moreau J, Rigaud $\mathrm{M}$, et al. (2003) Overexpression of cytosolic glutathione peroxidase (GPX1) delays endothelial cell growth and increases resistance to toxic challenges. Biochimie 85(6): 611-617.

24. Gupta SC, Patchva S, Aggarwal BB (2013) Therapeutic roles of curcumin: Lessons learned from clinical trials. AAPS J 15(1): 195-218.

25. Murni NS, Qamar UA, Siti ZM (2017) Antioxidant and antidiabetic effects of flavonoids A Structure-Activity relationship-based study. Biomed research international.

26. Nelson DR, Zeldin DC, Hoffman SM, Maltais LJ, Wain HM, et al. (2004) Comparison of cytochrome P450 (CYP) genes from the mouse and Human genomes, including nomenclature recommendations for genes, pseudogenes and alternative-splice variants. Pharmacogenetics 14 (1): $1-18$.

27. Borba MA, Melo Neto RP, Leitão GM, Castelletti CH, Lima Filho JL, et al. (2016) Evaluating the impact of missenses mutations in CYP2D6*7 and CYP2D6*14A Does it compromised tamoxifen metabolism? Pharmacogenomics 17: 573-582.

28. Chaudhry AS, Prasad B, Shirasaka Y, Fohner A, Finkelstein D, et al. (2015) The CYP2C19 intron 2 branch point SNP is the ancestral polymorphism contributing to the poor metabolizer phenotype in livers with CYP2C19*35 and CYP2C19*2 alleles. Drug Metab Dispos 43:1226-1235.

29. Fleeman N, McLeod C, Bagust A, Beale S, Boland A, et al. (2010) The clinical effectiveness and cost- effectiveness of testing for cytochrome P450 polymorphisms in patients with schizophrenia treated with antipsychotics A systematic review and economic evaluation. Health Technol. Assess 14(3): 151-157.

30. Ashkenazi A, Dixit VM (1998) Death receptors Signaling and modulation. Science 281(5381): 1305-1308. 
31. Fesik SW (2000) Insights into programmed cell death through structural biology. Cell 103(2): 273-282.

32. Tanaka M, Suda T, Takahashi T, Nagata S (2008) Expression of the functional soluble form of human fas ligand in activated lymphocytes. EMBO J 14(6): 1129-1135.

33. Peter ME, Krammer PH (2003) The CD95 (APO-1/Fas) DISC and beyond. Cell Death Differ 10(1): 26-35.

34. Boatright KM, Renatus M, Scott FL, Sperandio S, Shin H, et al. (2003) A unified model for apical caspase activation. Mol Cell 11(2): 529-541.

35. Chervonsky AV (1999) Apoptotic and effector pathways in autoimmunity. Curr Opin Immunol 11(6): 684-688.

36. Mercep M, Weissman AM, Frank SJ, Klausner RD, Ashwell JD, et al. (1989) Activation-driven programmed cell death and $\mathrm{T}$ cell receptor zeta eta expression. SCIENCE 246(4934): 1162-1165.

37. Wolf BB, Green DR (2006) Suicidal tendencies apoptotic cell death by caspase family proteinases. J Biol Chem 274(29): 20049-20052.

38. Jin H Park, Soon Suk K, Jae Yong K (2015) Hungwon Tchah Investigative Ophthalmology \& Visual Science. 56: 5614-5621.

39. Hla T, Neilson K (2003) Human cyclooxygenase-2 cDNA. Proc Natl Acad Sci USA 89(16): 7384-7388.

40. Rouzer CA, Marnett LJ (2009) Cyclooxygenases structural and functional insights. J Lipid Res 50: S29-S34.

41. Hochhauser D (2014) Cancer and its Management. John Wiley \& Sons p. 119.

42. McKay GA, Walters MR (2013) Non-Opioid Analgesics. Lecture Notes Clinical Pharmacology and Therapeutics. ( $9^{\text {th }}$ Edn.). Hoboken Wiley.

43. Ezekiel 00, Onyeoziri NF (2009) Preliminary studies on the antimicrobial properties of Buchholzia coriacea. African Journal of Biotechnology 8(3): 472-474.

44. Chika E, Ikegbunam M, Ugwu C, Araka O, Iroha IR, et al. (2012) Evaluation of antibacterial activity of the leaf extracts of Bulcchozia coriacea. Asian Journal of Pharmaceutical and Biological Research 2(4): 204-208.

45. Nweze NE (2011) Studies on the antioxidant and antimicrobial activities of the seed extracts of Buchholzia coriacea (Capparidaceae). Nigerian Veterinary Journal 32(2): 143-147.

46. Dimari J, Meggyesi J, Udvarhelyei N, Price P, Safirstein R, et al. (1997) $\mathrm{N}$-acetylcysteine ameliorates ischemic renal failure. Am J Physiol 272 292-298.

47. Erica H, Yelena B, Nahir AM (2002) N-Acetylcysteine enhances the action of anti-inflammatory drugs as suppressors of prostaglandin production in monocytes. Mediators Inflamm. 11(5): 321-323.

48. Franco R, Schoneveld OJ, Pappa A, Panayiotidis MI (2007) The central role of glutathione in the pathophysiology of human diseases. Archives of Physiology and Biochemistry 113(4-5): 234-258.

49. Hayes JD, Flanagan JU, Jowsey IR (2005) Glutathione transferases. Annu Rev Pharmacol Toxicol 45: 51-88.

50. Li YS, Hung SC, Wei YH, Tarng DC (2009) GST M1 polymorphism associates with DNA oxidative damage and mortality among hemodialysis patients. J Am Soc Nephrol 20: 405-415.

51. Josephy PD (2010) Genetic variations in human glutathione transferase enzymes significance for pharmacology and toxicology. Human Genomics and Proteomics 2010: 876940.

52. Bae YA (2016) Selective inhibition of cyclooxygenase (COX)-2 reverses inflammation and expression of COX-2 and interleukin 6 in rat adjuvant arthritis. Mol Biochem Parasito 16(1): 45-48

53. Ferguson-Smith AC, Chen YF, Newman MS, May LT, Sehgal PB, et al (1998) Regional localization of the interferon-beta 2/B-cell stimulatory factor 2 /hepatocyte stimulating factor gene to human chromosome 7 : 15-p21. Genomics 2(3): 203-208.
54. Heinrich PC, Castell JV, Andus T (1990) Interleukin-6 and the acute phase response. Biochem J 256(3): 621-636.

55. Gillmore JD, Lovat LB, Persey MR, Pepys MB, Hawkins PN (2010) Amyloid load and clinical outcome in AA amyloidosis in relation to circulating concentration of serum amyloid A protein. Lancet 358(9275): 24-29.

56. Nemeth E, Rivera S, Gabayan V, Keller C, Taudorf S, et al. (2004) IL-6 mediates hypoferremia of inflammation by inducing the synthesis of the iron regulatory hormone hepcidin. J Clin Invest 113(9): 1271-1276.

57. Luizzi JP, Lichten LA, Rivera S, Blanchard RK, Aydemir TB, et al. (2005) Interleukin-6 regulates the zinc transporter Zip14 in liver and contributes to the hypozincemia of the acute-phase response. Proc Nat Acad Sci 102(19): 6843-6848.

58. Ibiam UA, Alum EU, Orji OU, Aja PM, Ezeani NN (2018) Anti-inflammatory effects of Buchholzia coriacea ethanol leaf-extract and fractions in freund's adjuvant-induced rheumatoid arthritis albino ratsIndo American journal of pharmaceutical sciences 05(07): 6341-6357.

59. Mata M, Morcillo E, Gimeno C (2011) (NAC) inhibit mucin synthesis and pro-inflammatory mediators in alveolar type II epithelial cells infected with influenza virus A and B and with respiratory syncytial virus (RSV) Bio chem Pharmacol 82: 548-555.

60. Laura IA, Martinez M, Padovani CR, Martinez FE (2003) Ultrastructural and morphometric analysis on the ovary of Wistar rats after chronic ethanol ingestion. Journal of submicroscopic cytology and pathology 35(2): 167-176.

61. Funk CD, Funk LB, Kennedy ME, Pong AS, Fitzgerald GA (2004) Human platelet/erythroleukemia cell prostaglandin $\mathrm{G} / \mathrm{H}$ synthase cDNA cloning, expression, and gene chromosomal assignmentFASEB. Journal 5(9): 2304-2312

62. Smith, WL, DeWitt DL (2006) Prostaglandin endoperoxide H synthases -1 and -2 . Adv Immunol 62167-215.

63. Tiley SL, Coffman TM, Koller BH (2011) Prostaglandin in inflammatory response. J Clinical Invest 10815-23.

64. Laine L, Takeuchi K, Tarnawski A (2010) Gastric mucosal defense and cytoprotection bench to bedside. Gastroenterology 135(1): 41-60

65. Herschman HR, Reddy ST, Xie W (2005) Function and regulation of prostaglandin synthase 2. Adv Exp Med Biol 407: 61-66.

66. Ancha HR, Kurella RR, McKimmey CC, Lightfoot S, Harty RF (2009) Effects of $\mathrm{N}$-acetylcysteine plus mesalamine on prostaglandin synthesis and nitric oxide generation in TNBS induced colitis in rats. Digestive diseases and sciences 54(4): 758-766.

67. Mosly S, Uetrecht J, Shear N (2007) Idiosyncratic drug reactions the reactive metabolite syndromeLancet 356: 1587-1591.

68. Yang J, Li YU, Ski TW (2015) Identification of a new ribose methylation in 18s Rrna of S cervisiae. Nucleic acid Res 43(4): 2342-235.

69. Meyerm JH, Sabatos CA (2005) The TIM gene family regulate autoimmune and allergic diseases, Trend Mol Med 11: 362-369.

70. Lim AI, Tang S, Lai K (2013) Kidney injury molecule 1: More than just an injury marker of tubular epithelial cells? J cell physiol 228(5): 917-924.

71. Sakasi D, Yamada A, Umeno H (2011) Comparison of the course of biomarker changes and kidney injury in a rat model of drug-induced acute kidney injury. Biomarkers16(7): 553-566.

72. Vaidya VS, Ozer JS, Dieterle F (2010) Kidney injury molecule-1 outperforms traditional biomarkers of kidney injury in preclinical biomarker qualification studies Nat Biotechnol 28(5): 478-485.

73. Han WK, Waiker SS, Johnson A (2008) Urinary biomarker in the early diagnosis of acute kidney injuryKid int 73: 863-869.

74. Sancho Martnez SM, Piedrafita F, Cannata-Andía JB, López-NovoaJM, López-Hernández FJ (2011) Necrotic concentrations of cisplatin activate the apoptotic machinery but inhibit effector caspases and interfere with the execution of apoptosisToxicol Sci 22(1): 73-85. 
75. Ichimura T, Bonventre JV, Bailly V (1998) Kidney injury molecule-1 (KIM-1) a putative epithelial cell adhesion molecule containing a novel immunoglobulin domain, is up-regulated in renal cells after injury. J Bio Chem 273(1): 4135-4142.

76. Yu YL, Yiang GT, Chou PL (2014) Due role of acetaminophen in prompting hepatoma cell apoptosis and kidney fibroblast proliferation. Mol Med Rep 9(6): 2077-2084.

77. Sao, T (2012) Health implications of Mediterranean diets in light of contemporary knowledge, I plant foods and dairy products. Am J Clin

\section{ISSN: 2574-1241}

DOI: $10.26717 /$ BJSTR.2020.26.004364

Olusola A0. Biomed J Sci \& Tech Res

(c) (i) This work is licensed under Creative

Submission Link: https://biomedres.us/submit-manuscript.php
Nutr 61: 1407-1415.

78. Wang H, Duan J, Yuang H, Zhang L, Zhang W, et al. (2007) Chinese Journal of chromatography. 25(4) 453-456.

BIOMEDICAL
RESEARCHES $\quad \begin{aligned} & \text { Assets of Publishing with us } \\ & \text { - Global archiving of articles }\end{aligned}$

